TITLE:

\title{
Visible-Light-Assisted Selective Catalytic Reduction of Nitric Oxide with Ammonia over Dye-Modified Titania Photocatalysts
}

\section{$\operatorname{AUTHOR}(S)$ :}

Yamamoto, Akira; Teramura, Kentaro; Hosokawa, Saburo; Shishido, Tetsuya; Tanaka, Tsunehiro

\section{CITATION:}

Yamamoto, Akira ... [et al]. Visible-Light-Assisted Selective Catalytic Reduction of Nitric Oxide with Ammonia over Dye-Modified Titania Photocatalysts. ChemCatChem 2015, 7(12): 1818-1825

\section{ISSUE DATE:}

2015-05-12

\section{URL:}

http://hdl.handle.net/2433/201597

\section{RIGHT:}

This is the peer reviewed version of the following article: Yamamoto, A., Teramura, K., Hosokawa, S., Shishido, T. and Tanaka, T. (2015), Visible-Light-Assisted Selective Catalytic Reduction of Nitric Oxide with Ammonia over Dye-Modified Titania Photocatalysts. ChemCatChem, 7: 1818-1825, which has been published in final form at

http://dx.doi.org/10.1002/cctc.201500207. This article may be used for non-commercial purposes in accordance with Wiley Terms and Conditions for Self-Archiving.; The full-text file will be made open to the public on 12 May 2016 in accordance with publisher's 'Terms and Conditions for Self-Archiving': この論文は出版社版でありません。引用の際に は出版社版をご確認ご利用ください。; This is not the published version. Please cite only the published version. 


\title{
Visible-Light-Assisted Selective Catalytic Reduction of NO with $\mathrm{NH}_{3}$ over Dye-Modified $\mathrm{TiO}_{2}$ Photocatalysts
}

\author{
Akira Yamamoto ${ }^{[a]}$ Kentaro Teramura, ${ }^{[a, b, c]}$ Saburo Hosokawa, ${ }^{[a, b]}$ Tetsuya Shishido, ${ }^{[b, d]}$ and Tsunehiro \\ Tanaka*[a,b] $^{*}$
}

\begin{abstract}
Dye-modified $\mathrm{TiO}_{2}$ photocatalysts showed high photocatalytic activity for the selective catalytic reduction of NO with $\mathrm{NH}_{3}$ in the presence of $\mathrm{O}_{2}$ under visible-light irradiation. Among the 15 dyes investigated, the maximum conversion was achieved using a $\mathrm{Ru}\left(2,2^{\prime} \text {-bipyridyl-4,4'-dicarboxylic acid }\right)_{2}(\mathrm{NCS})_{2}$ complex (N3-dye) for the modification of $\mathrm{TiO}_{2}$ (NO conversion $>99 \%, \mathrm{~N}_{2}$ selectivity > $99 \%$ ). Diffuse reflectance infrared Fourier transform (DRIFT) investigation showed that nitrite $\left(\mathrm{NO}_{2}^{-}\right)$and nitrate $\left(\mathrm{NO}_{3}^{-}\right)$species were generated on the $\mathrm{N} 3-\mathrm{TiO}_{2}$ surface under visible-light irradiation. In gas switch reactions, $\mathrm{NO}_{2}^{-}$on the $\mathrm{N} 3-\mathrm{TiO}_{2}$ surface became $\mathrm{N}_{2}$ by a reaction with adsorbed $\mathrm{NH}_{3}$ under visible-light irradiation, although $\mathrm{NO}_{3}{ }^{-}$reacted with $\mathrm{NH}_{3}$ to form $\mathrm{N}_{2}$ and $\mathrm{N}_{2} \mathrm{O}$. Based on the relativity with $\mathrm{NH}_{3}$, we concluded that the $\mathrm{NO}_{2}^{-}$species is an intermediate in photo-SCR and reacts with $\mathrm{NH}_{3}$ adsorbed on the surface of $\mathrm{N} 3-\mathrm{TiO}_{2}$ under visible-light irradiation to selectively form $\mathrm{N}_{2}$.
\end{abstract}

\section{Introduction}

Nitrogen oxides $\left(\mathrm{NO}_{x}\right)$ are air pollutants and cause serious environmental problems, including acid rain and town smog. The removal of $\mathrm{NO}_{x}$ in exhaust gases that contain excess $\mathrm{O}_{2}$ is an important process in air purification. Typically, $\mathrm{NO}_{x}$ are decomposed to harmless $\mathrm{N}_{2}$ using selective catalytic reduction with ammonia $\left(\mathrm{NH}_{3}-\mathrm{SCR}\right)$ over vanadium oxide-based catalysts ${ }^{[1]}$ and Fe- or Cu-zeolite catalysts, ${ }^{[2]}$ according to eq. 1.

[a] A. Yamamoto, Dr. K. Teramura, Dr. S. Hosokawa, Prof. Dr. T. Tanaka

Department of Molecular Engineering

Graduate School of Engineering, Kyoto University

Kyoto Daigaku Katsura, Nishikyo-ku, Kyoto 615-8510 (Japan)

Fax: (+ 81)75-383-2561

E-mail: tanakat@moleng.kyoto-u.ac.jp

teramura@moleng.kyoto-u.ac.jp

[b] Dr. K. Teramura, Dr. S. Hosokawa, Prof. Dr. T. Shishido, Prof. Dr. T. Tanaka

Elements Strategy Initiative for Catalysts and Batteries

Kyoto University

Kyoto Daigaku Katsura, Nishikyo-ku, Kyoto 615-8520 (Japan)

[c] Dr. K. Teramura

Precursory Research for Embryonic Science and Technology

(PRESTO), Japan Science and Technology Agency (JST)

4-1-8 Honcho, Kawaguchi, Saitama 332-0012 (Japan)

[d] Prof. Dr. T. Shishido

Department of Applied Chemistry

Tokyo Metropolitan University

Hachioji, Tokyo 192-0397 (Japan)

Supporting information for this article is given via a link at the end of the document.
$4 \mathrm{NO}+4 \mathrm{NH}_{3}+\mathrm{O}_{2} \rightarrow 4 \mathrm{~N}_{2}+6 \mathrm{H}_{2} \mathrm{O}$

These catalysts, however, cannot efficiently remove $\mathrm{NO}_{x}$ from diesel engines during cold start condition $(<473 \mathrm{~K}) .{ }^{[3]}$ Therefore, novel catalysts that can perform $\mathrm{NH}_{3}-\mathrm{SCR}$ at low temperatures are strongly required.

We have reported photocatalysts that show activity for $\mathrm{NH}_{3}-\mathrm{SCR}$ at low temperatures in the presence of excess $\mathrm{O}_{2}$ (referred to as photo-SCR) ${ }^{[4]}$ The reaction mechanism of photo-SCR has been investigated by us and other groups using spectroscopic, ${ }^{[5]}$ kinetic, ${ }^{[4 b, 6]}$ and theoretical ${ }^{[7]}$ methods. Over $\mathrm{TiO}_{2}$ photocatalyst, the conversion of $\mathrm{NO}$ and the selectivity to $\mathrm{N}_{2}$ becomes $90 \%$ and $99 \%$, respectively, at a gas hourly space velocity (GHSV) of $8000 \mathrm{~h}^{-1}$, which is sufficient for the De-NO $\mathrm{N}_{x}$ process in typical stationary sources such as power plants, blast furnaces, and incinerators. However, higher GHSV values $\left(>50000 \mathrm{~h}^{-1}\right)$ are required in diesel engines owing to the limited installation space of the De-NO process and a high flow rate of the exhaust gas. Recently, we reported that porphyrin-sensitized $\mathrm{TiO}_{2}$ functions as a visible-light-sensitive photocatalyst for $\mathrm{NH}_{3}-\mathrm{SCR}$. This reaction proceeds via electron injection from photo-excited dyes into the conduction band of $\mathrm{TiO}_{2}$ (dye-sensitization mechanism) ${ }^{[8]}$ although a detailed mechanism of the reaction is unclear. The electron injection process from photo-excited dyes into the conduction band of a semiconductor is an important step in dye-sensitized solar cells (DSSCs) ${ }^{[9]}$ and dye-sensitized photocatalysts, ${ }^{[10]}$ and has been previously investigated. ${ }^{[11]}$ Many researchers have tested various dyes, including $\mathrm{Ru}$ complexes, ${ }^{[12]}$ porphyrins, ${ }^{[13]}$ phthalocyanines, ${ }^{[14]}$ and other organic dyes, ${ }^{[9 b, 10 c, 15]}$ to improve the performance of DSSCs and dye-sensitized photocatalysts. The type of dye used for the modification of semiconductors has a great impact on the performance of DSSCs and dye-sensitized photocatalysts, and thus, should have a significant effect on the activity in photoSCR under visible-light irradiation. A major problem of the dyesensitization system is the stability of the dyes; moreover, optimization of the dye is essential to evaluate and improve the performance of photo-SCR over dye-modified $\mathrm{TiO}_{2}$ photocatalysts. Herein, we investigated photo-SCR under visible-light irradiation using $\mathrm{TiO}_{2}$ photocatalysts modified with 15 different dyes (Fig. 1). The reactivity of the adsorbed intermediates generated over the dye-modified $\mathrm{TiO}_{2}$ photocatalyst were also investigated by means of in situ diffuse reflectance infrared Fourier transform (DRIFT) and UV-Vis diffuse reflectance (DR) spectroscopies to elucidate the reaction mechanism. 


\section{Results and Discussion}

Screening of dyes. Fig. 2 shows the results of photo-SCR over dye-modified $\mathrm{TiO}_{2}$ photocatalysts. The reaction proceeded to some extent (ca. $5 \%$ ) over a bare $\mathrm{TiO}_{2}$ photocatalyst under visible-light irradiation, as reported in the previous paper. ${ }^{[16]}$ Modification of $\mathrm{TiO}_{2}$ with various dyes greatly enhanced photoSCR activities. The maximum conversion of $\mathrm{NO}$ (>99\%) was obtained using an N3-dye (1 in Fig. 1)-modified $\mathrm{TiO}_{2}$ photocatalyst $\left(\mathrm{N}_{3}-\mathrm{TiO}_{2}\right)$ after $30 \mathrm{~min}$. The conversion of $\mathrm{NO}$ was significantly higher than those of other photocatalysts (e.g., UVlight irradiated $\left.\mathrm{TiO}_{2}\right)^{[4 \mathrm{~d}, 8]}$ and conventional catalysts (e.g., $\mathrm{Fe}$ and Cu-zeolite catalysts) ${ }^{[17]}$ at low temperatures. $\mathrm{N}_{2} \mathrm{O}$ was not detected in all reactions shown in Fig. 2. The high selectively to $\mathrm{N}_{2}$ is consistent with our previous reports of photo-SCR over porphyrin-modified $\mathrm{TiO}_{2}$ photocatalysts under visible-light irradiation. ${ }^{[8]}$ The order of activities is discussed in the last section.

The conversion of NO was almost stable over $180 \mathrm{~min}$ of visiblelight irradiation over the $\mathrm{TiO}_{2}$ photocatalysts modified with $\mathrm{Ru}(\mathrm{bpy})_{3} \mathrm{Cl}_{2}$ 4, TCPP 7, phthalocyanines 9 and 11, and $\mathrm{RhCl}_{3} 12$ A relatively high stability was observed in the case of N3-dye (1), and the $\mathrm{N} 3-\mathrm{TiO}_{2}$ photocatalyst showed the highest conversion of $\mathrm{NO}$ even at $180 \mathrm{~min}(95 \%)$. When xanthene dyes were used, relatively high conversions of $\mathrm{NO}$ were obtained after $30 \mathrm{~min}$; rose bengal 2 (81\%), eosin Y $3(80 \%)$, and rhodamine B 5 (63\%) However, as shown by the time course of photo-SCR (Fig. 3), conversions gradually decreased over $180 \mathrm{~min}$ of the reaction. Bleaching of the catalyst colors was observed after the reaction, which suggests that the decrease in the activity was due to dye decomposition. The low stability of xanthene dyes was consistent with previously reported DSSCs. ${ }^{[9 b, 18]}$ Thus, the xanthene dyes were deemed unsuitable for photo-SCR.

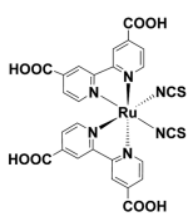
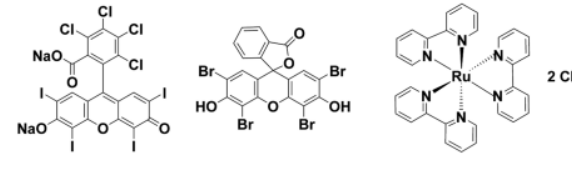

N3 dye

(1)

Rose bengal Eosin $\mathrm{Y}$

$\mathrm{Ru}(\text { bpy })_{3} \mathrm{Cl}_{2}$

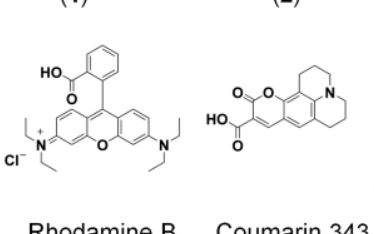

(5)

(6)

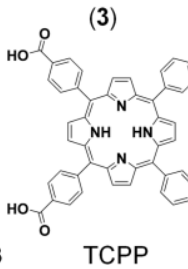

(7)

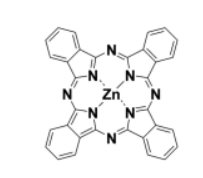

Zn phthalocyanine

(9)

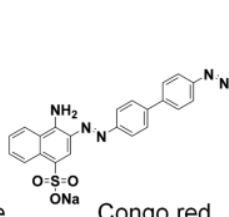

ONa
$\mathrm{O}=\mathrm{S}=0$

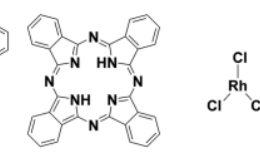

Phthalocyanine $\quad \mathrm{RhCl}_{3}$ (10)

(11)

(12)
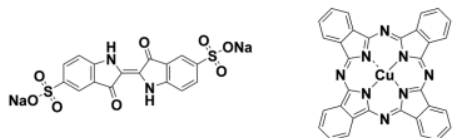

Indigo carmine

(13)
Cu phthalocyanine

(14)

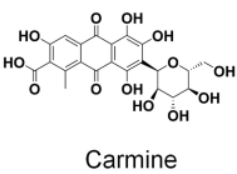

(15)
Figure 1. Schematic representation of dyes.

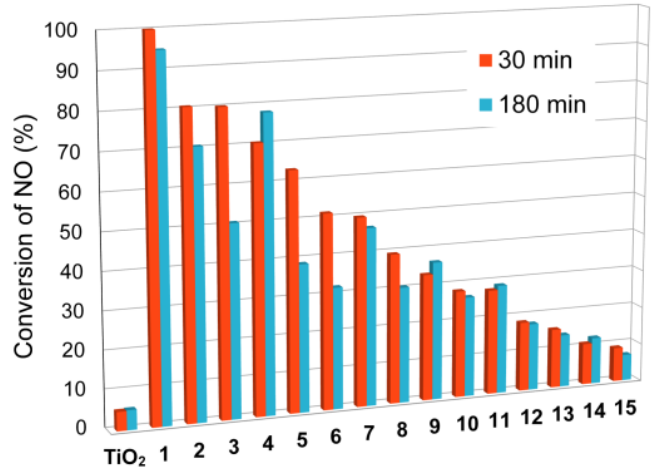

Figure 2. Conversion of $\mathrm{NO}$ in photo-SCR over the dye-modified $\mathrm{TiO}_{2}$ photocatalysts under visible-light irradiation. Dye loading: $12.5 \mu \mathrm{mol} \mathrm{g}{ }^{-1}$. GHSV: $100000 \mathrm{~h}^{-1}$. The numbers in the bottom axis correspond to those in Fig.1. 


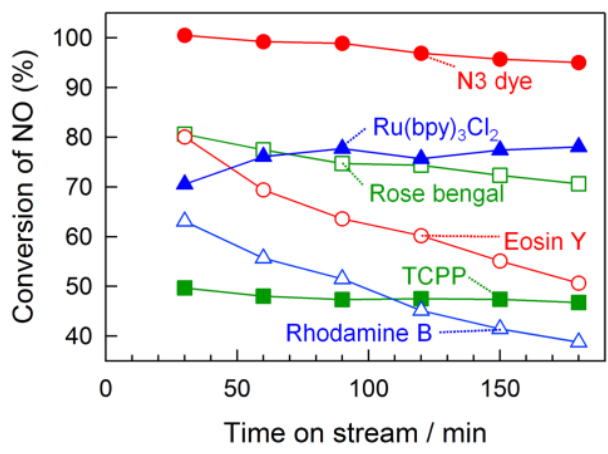

Figure 3. Time course of the conversion of NO in photo-SCR over the dyemodified $\mathrm{TiO}_{2}$ photocatalysts under visible-light irradiation. Dye loading: 12.5 $\mu \mathrm{mol} \mathrm{g}{ }^{-1}$. GHSV: $100000 \mathrm{~h}^{-1}$.

Reactivity of adsorbed species of $\mathrm{NH}_{3}$ and NO. Table 1 lists the results of reactions under various conditions. Efficient $\mathrm{N}_{2}$ formation was observed over $\mathrm{N}_{3}-\mathrm{TiO}_{2}$ in the presence of $\mathrm{NO}$, $\mathrm{NH}_{3}$, and $\mathrm{O}_{2}$ under visible-light irradiation (640 ppm, entry 2). The activity of $\mathrm{N}_{3}-\mathrm{TiO}_{2}$ was significantly higher than that of a bare $\mathrm{TiO}_{2}$ photocatalyst under UV and visible light irradiation (290 ppm, entry 1). Product formation was greatly diminished without $\mathrm{NO}, \mathrm{NH}_{3}$, or $\mathrm{O}_{2}$ (entries 3, 4, and 5), which indicated that all the gases are involved in the formation of $\mathrm{N}_{2}$. Furthermore, visible-light irradiation drastically promoted photo-SCR over N3$\mathrm{TiO}_{2}$ (entry 6).

A couple of gas switch experiments were carried out to investigate the reactivity of the adsorbed species of $\mathrm{NH}_{3}$ and $\mathrm{NO}$ on the $\mathrm{N} 3-\mathrm{TiO}_{2}$ surface. In the first experiment, $\mathrm{NH}_{3} / \mathrm{He}$ gas was flowed in the first $120 \mathrm{~min}$ in the dark (Fig. 4(A)), and no product was observed. Subsequently, the feed gas was switched to $\mathrm{NO} / \mathrm{O}_{2} / \mathrm{He}$ gas and visible-light irradiation was started. Selective formation of $\mathrm{N}_{2}$ (910 ppm, selectivity to $\mathrm{N}_{2}>99 \%$ ) was observed after 5 min of visible-light irradiation. The concentration of $\mathrm{N}_{2}$ in the outlet gas gradually decreased with increasing visible-light irradiation time and dropped to $24 \mathrm{ppm}$ after $270 \mathrm{~min}$. This formation of $\mathrm{N}_{2}$ presumably derived from the reaction between the initially adsorbed $\mathrm{NH}_{3}$ and $\mathrm{NO}$ in the gas phase, because low amounts $\mathrm{N}_{2}$ were formed via a reaction between $\mathrm{NO}$ and $\mathrm{O}_{2}$ under visible-light irradiation (Table 1, entry 4).

In the second experiment, $\mathrm{NO} / \mathrm{O}_{2} / \mathrm{He}$ gas was flowed under visible-light irradiation for $90 \mathrm{~min}$, and then the feed gas was switched to $\mathrm{NH}_{3} / \mathrm{He}$ gas in the dark (Fig. 4(B)). During this period, a small amount of $\mathrm{N}_{2}$ was formed and $\mathrm{N}_{2} \mathrm{O}$ was not detected. After 120 min of the $\mathrm{NH}_{3} / \mathrm{He}$ gas flow in the dark, visible-light irradiation was started and $\mathrm{N}_{2}(780 \mathrm{ppm})$ and $\mathrm{N}_{2} \mathrm{O}(130 \mathrm{ppm})$ were observed (selectivity to $\mathrm{N}_{2}: 86 \%$ ) after $5 \mathrm{~min}$; the concentrations gradually decreased as the irradiation time was increased. The blank test results showed that $\mathrm{NH}_{3}$ did not decompose to $\mathrm{N}_{2}$ over $\mathrm{N}_{3}-\mathrm{TiO}_{2}$ under visible-light irradiation (Table 1, entry 3). Accordingly, this formation of $\mathrm{N}_{2}$ and $\mathrm{N}_{2} \mathrm{O}$ was due to the reaction between the adsorbed $\mathrm{NH}_{3}$ and the surface $\mathrm{NO}_{x}$ species formed by the addition of $\mathrm{NO} / \mathrm{O}_{2} / \mathrm{He}$ gas under visible-light irradiation. The $\mathrm{NO}_{x}$ species on the surface of N3$\mathrm{TiO}_{2}$ did not react with $\mathrm{NH}_{3}$ without visible-light irradiation, which indicated that visible-light was essential for this surface reaction. Based on the gas switch experiment, we concluded that surface $\mathrm{NO}_{x}$ species became $\mathrm{N}_{2}$ and $\mathrm{N}_{2} \mathrm{O}$ by a reaction with adsorbed $\mathrm{NH}_{3}$ on the $\mathrm{N} 3-\mathrm{TiO}_{2}$ surface under visible-light irradiation (Langmuir-Hinshelwood mechanism).

Table 1. Result of photo-SCR under various reaction conditions.

\begin{tabular}{|c|c|c|c|c|c|c|c|}
\hline \multirow{2}{*}{ Entry } & \multirow{2}{*}{ Catalyst } & \multicolumn{3}{|c|}{ Inlet $(\%)^{[a]}$} & \multirow{2}{*}{ Lamp $^{[\mathrm{b}]}$} & \multicolumn{2}{|c|}{ Outlet (ppm) } \\
\hline & & NO & $\mathrm{NH}_{3}$ & $\mathrm{O}_{2}$ & & $\mathrm{~N}_{2}$ & $\mathrm{~N}_{2} \mathrm{O}$ \\
\hline 1 & $\mathrm{TiO}_{2}$ & 0.1 & 0.1 & 2 & UV+Vis. & 290 & 4 \\
\hline 2 & $\mathrm{~N} 3-\mathrm{TiO}_{2}{ }^{[\mathrm{d}]}$ & 0.1 & 0.1 & 2 & Vis. & 640 & n.d. ${ }^{[\mathrm{e}]}$ \\
\hline 3 & $\mathrm{~N} 3-\mathrm{TiO}_{2}{ }^{[\mathrm{d}]}$ & 0 & 0.1 & 2 & Vis. & 14 & n.d. ${ }^{[e]}$ \\
\hline 4 & $\mathrm{~N} 3-\mathrm{TiO}_{2}{ }^{[\mathrm{d}]}$ & 0.1 & 0 & 2 & Vis. & 10 & n.d. ${ }^{[\mathrm{e}]}$ \\
\hline 5 & $\mathrm{~N} 3-\mathrm{TiO}_{2}{ }^{[\mathrm{d}]}$ & 0.1 & 0.1 & 0 & Vis. & 35 & 7 \\
\hline 6 & $\mathrm{~N} 3-\mathrm{TiO}_{2}{ }^{[\mathrm{d}]}$ & 0.1 & 0.1 & 2 & OFF & 15 & n.d. ${ }^{[\mathrm{e}]}$ \\
\hline 7 & $\mathrm{~N} 3-\mathrm{SiO}_{2}{ }^{[\mathrm{d}]}$ & 0.1 & 0.1 & 2 & Vis. & 16 & n.d. ${ }^{[e]}$ \\
\hline
\end{tabular}

[a] Concentration of $\mathrm{N}_{2}$ and $\mathrm{N}_{2} \mathrm{O}$ in the inlet gas. [b] Light source, UV+Vis: $300 \mathrm{~W}$ Xe lamp without cut-off filter, Vis: $300 \mathrm{~W}$ Xe lamp with L-42 cut-off filter. [c] Concentration of $\mathrm{N}_{2}$ and $\mathrm{N}_{2} \mathrm{O}$ in the outlet gas. GHSV: $250000 \mathrm{~h}$

, total flow rate: $500 \mathrm{ml} \mathrm{min}^{-1}$, catalyst amount: $110 \mathrm{mg}$. [d] Loading of N3-dye: $37.5 \mu \mathrm{mol} \mathrm{g}^{-1}$. [e] Not detected.

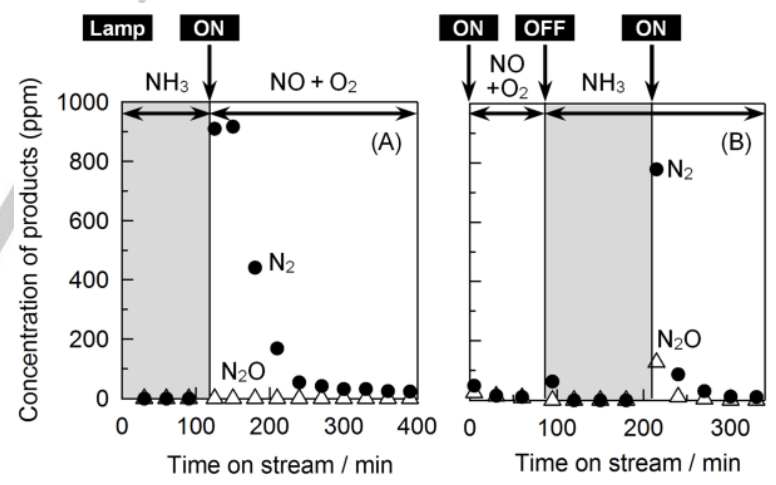

Figure 4. Time course of concentration of $\mathrm{N}_{2}$ and $\mathrm{N}_{2} \mathrm{O}$ in the outlet gas in the gas switch reactions. Catalyst: $37.5 \mu \mathrm{mol} \mathrm{g}{ }^{-1} \mathrm{~N} 3-\mathrm{TiO}_{2}, \mathrm{NO}: 1000 \mathrm{ppm}, \mathrm{NH}_{3}$ : $1000 \mathrm{ppm}, \mathrm{O}_{2}: 2 \%$, He: balance. GHSV: $8000 \mathrm{~h}^{-1}$, Light source: $300 \mathrm{~W} \mathrm{Xe}$ lump equipped with a $\mathrm{L} 42$ cut-off filter.

DRIFT investigations of surface $\mathrm{NO}_{x}$ species. Fig. 5 represents the DRIFT spectra before and after the addition of $\mathrm{NO} / \mathrm{O}_{2} / \mathrm{He}$ gas in the dark. The spectrum before the addition was used as the baseline. Two peaks, at 1478 and $1198 \mathrm{~cm}^{-1}$, gradually increased with increasing the exposure time (Fig. 5(A)). The peak at $1478 \mathrm{~cm}^{-1}$ was assigned to a $v_{3}$ vibration of monodentate $\mathrm{NO}_{2}^{-}$adsorbed on the surface of $\mathrm{N} 3-\mathrm{TiO}_{2}$. This species is also expected to have a $v_{1}$ vibration band between 1065 and $1050 \mathrm{~cm}^{-1}$. ${ }^{[19]}$ In the DRIFT experiment, a shoulder band was observed around that region, which supports its 
proposed generation. The peak at $1198 \mathrm{~cm}^{-1}$ was assigned to a bridged bidentate $\mathrm{NO}_{2}^{-}$in a previous paper. ${ }^{[19]}$ Three negative peaks at 3697,3659 , and $3631 \mathrm{~cm}^{-1}$, and a broad positive peak around $3500 \mathrm{~cm}^{-1}$ appeared after the addition of $\mathrm{NO} / \mathrm{O}_{2} / \mathrm{He}$ gas (Fig. 5(B)). The negative peaks were assigned to isolated $\mathrm{OH}$ groups in different surroundings (e.g., number of coordinated $\mathrm{Ti}$ atom, valence of coordinated $\mathrm{Ti}$ atom, surface sites of $\left.\mathrm{TiO}_{2}\right)^{[20]}$ and the broad positive peak was attributed to a hydrogenbonded $\mathrm{OH}$ group. We did not observe a characteristic band of deformation vibration of water molecules around $1640 \mathrm{~cm}^{-1}$, which indicated that the amount of adsorbed water did not change by the co-adsorption of $\mathrm{NO}$ and $\mathrm{O}_{2}$. Thus, the increase of the band intensity centered at $3500 \mathrm{~cm}^{-1}$ is not due to the adsorption of water molecules generated. The change in the $\mathrm{OH}$ region suggests that the adsorbed $\mathrm{NO}_{2}^{-}$species interacted with the isolated $\mathrm{OH}$ groups through hydrogen bonding, thus reducing the band intensities of the isolated $\mathrm{OH}$ groups and increasing the hydrogen-bond-related band intensity. Both $\mathrm{NO}_{2}^{-}$ species (monodentate and bridged bidentate) were generated on the surface of $\mathrm{N} 3-\mathrm{TiO}_{2}$ by the co-adsorption of $\mathrm{NO}$ and $\mathrm{O}_{2}$ in the dark.

After 30 min of $\mathrm{NO} / \mathrm{O}_{2}$ gas flow, $\mathrm{O}_{2} / \mathrm{He}$ gas was introduced to the DRIFT cell, and then visible-light irradiation was started across the $\mathrm{KBr}$ window. As shown in Fig. $6(\mathrm{~A})$, the band at $1478 \mathrm{~cm}^{-1}$ decreased with visible-light irradiation, which indicated that the $\mathrm{NO}_{2}{ }^{-}$species were consumed by the reaction with $\mathrm{O}_{2}$ under visible-light irradation. New bands at 1605, 1583, 1297, and $1253 \mathrm{~cm}^{-1}$ increased with increasing irradiation time. Bands at 1605 and $1253 \mathrm{~cm}^{-1}$ were attributed to a $v_{3}$ vibration of the bridging bidentate nitrate $\left(\mathrm{NO}_{3}^{-}\right)$, and a set of bands at 1583 and $1297 \mathrm{~cm}^{-1}$ was assigned to the chelating bidentate $\mathrm{NO}_{3}{ }^{-[19]}$ Thus, the $\mathrm{NO}_{2}^{-}$species was oxidized into the $\mathrm{NO}_{3}^{-}$species under visible-light irradiation. In the $\mathrm{OH}$ region (Fig. 6(B)), the isolated $\mathrm{OH}$ bands at 3697,3659 , and $3631 \mathrm{~cm}^{-1}$ decreased with visible-light irradiation, suggesting that the surface $\mathrm{OH}$ groups reacted with the adsorbed $\mathrm{NO}_{2}^{-}$to form $\mathrm{NO}_{3}{ }^{-}$. The DRIFT investigation revealed that the $\mathrm{NO}_{2}^{-}$species appeared after the co-adsorption of $\mathrm{NO}$ and $\mathrm{O}_{2}$ in the dark, and were oxidized into $\mathrm{NO}_{3}{ }^{-}$by $\mathrm{O}_{2}$ under visible-light irradiation (Scheme 1).

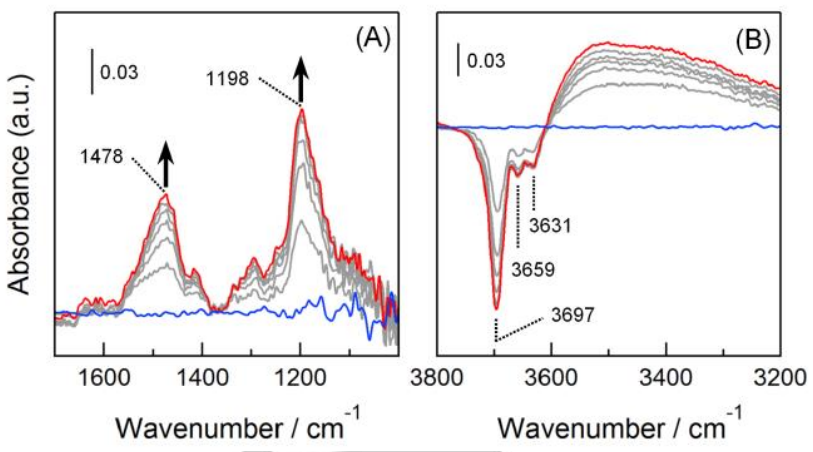

Figure 5. DRIFT spectra of $\mathrm{N} 3-\mathrm{TiO}_{2}$ in the dark before addition of $\mathrm{NO} / \mathrm{O}_{2} / \mathrm{He}$ gas (blue line), and after 5, 10, 15, 20, 25 (grey lines), and 30 min (red line).

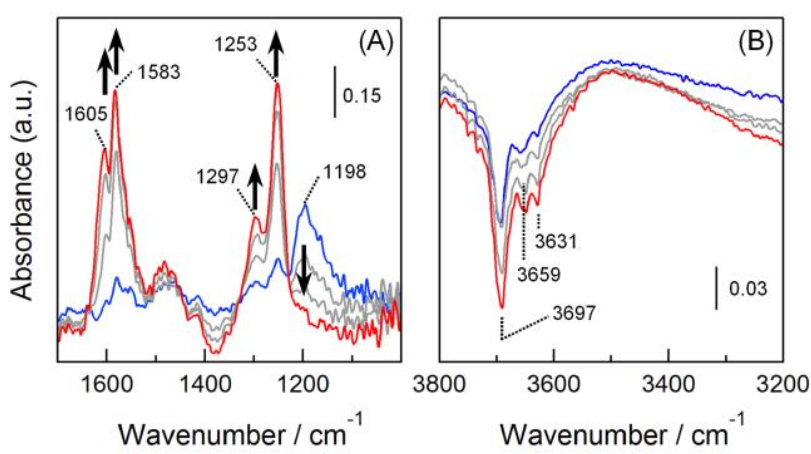

Figure 6. DRIFT spectra of $\mathrm{N}_{3}-\mathrm{TiO}_{2}$ in $\mathrm{O}_{2} / \mathrm{He}$ gas before visible-light irradiation (blue line), and after $20 \mathrm{~min}, 40 \mathrm{~min}$ (grey lines), and $60 \mathrm{~min}$ (red line) from the start of visible-light irradiation.

Reactivity of the $\mathrm{NO}_{2}^{-}$and $\mathrm{NO}_{3}^{-}$species with $\mathrm{NH}_{3}$ under visible-light irradiation. Either $\mathrm{NaNO}_{2}$ or $\mathrm{NaNO}_{3}$ was impregnated over $\mathrm{N}^{-}-\mathrm{TiO}_{2}$ in order to investigate the reactivity of $\mathrm{NO}_{2}^{-}$and $\mathrm{NO}_{3}^{-}$on the surface of $\mathrm{N} 3-\mathrm{TiO}_{2} . \mathrm{NH}_{3}$ was flowed into the reactor filled with the $\mathrm{NaNO}_{3}$ - or $\mathrm{NaNO}_{2}$-impregnated catalysts (Fig. 7). In the dark, $\mathrm{N}_{2}$ and $\mathrm{N}_{2} \mathrm{O}$ were not detected in an $\mathrm{NH}_{3} / \mathrm{He}$ gas flow for both catalysts. For the $\mathrm{NaNO}_{3}-$ impregnated $\mathrm{N}-\mathrm{TiO}_{2}, \mathrm{~N}_{2}$ (2020 ppm) and $\mathrm{N}_{2} \mathrm{O}$ (1420 ppm) were observed after 5 min of visible-light irradiation. Not much $\mathrm{N}_{2}$ was observed in the $\mathrm{NH}_{3} / \mathrm{He}$ gas flow under visible-light irradiation in the blank tests (Table 1, entry 3 ). Thus, the generated $N_{2}$ shown in Fig. $7(\mathrm{~A})$ is derived from a reaction between $\mathrm{NH}_{3}$ in the gas phase and $\mathrm{NO}_{3}{ }^{-}$species on the surface of $\mathrm{N} 3-\mathrm{TiO}_{2}$. Surprisingly, a large amount of $\mathrm{N}_{2} \mathrm{O}$ was detected in this experiment (selectivity to $\mathrm{N}_{2}=59 \%$ ). In contrast, selective formation of $\mathrm{N}_{2}$ was observed from the $\mathrm{NaNO}_{2}$-impregnated $\mathrm{N}_{3}-\mathrm{TiO}_{2}$ under visible-light irradiation (Fig. $7(\mathrm{~B})$, selectivity to $\mathrm{N}_{2}=94 \%$ ), which suggested that $\mathrm{NO}_{2}^{-}$became $\mathrm{N}_{2}$ on reacting with $\mathrm{NH}_{3}$. As shown above, the reactivity of $\mathrm{NO}_{2}^{-}$with $\mathrm{NH}_{3}$ was significantly different from that of $\mathrm{NO}_{3}{ }^{-}$in terms of selectivity to $\mathrm{N}_{2}$ (Scheme 1), which could explain the relatively low selectivity to $N_{2}$ (selectivity to $N_{2}$ $=86 \%)$ in the gas switch reaction shown in Fig. 4(B); both the $\mathrm{NO}_{2}{ }^{-}$and $\mathrm{NO}_{3}{ }^{-}$species were formed in $\mathrm{NO} / \mathrm{O}_{2} / \mathrm{He}$ gas under visible-light irradiation on the surface of $\mathrm{N}_{3}-\mathrm{TiO}_{2}$ and reacted with $\mathrm{NH}_{3}$. High selectivity to $\mathrm{N}_{2}(>99 \%)$ in photo-SCR in the presence of $\mathrm{NO}, \mathrm{NH}_{3}$, and $\mathrm{O}_{2}$ (Table 1, entry 1) over $\mathrm{N}_{3}-\mathrm{TiO}_{2}$ strongly indicated that an intermediate in photo-SCR was $\mathrm{NO}_{2}{ }^{-}$ was adsorbed on the surface of $\mathrm{N}_{3}-\mathrm{TiO}_{2}$ on the based of the difference in their reactivity. 

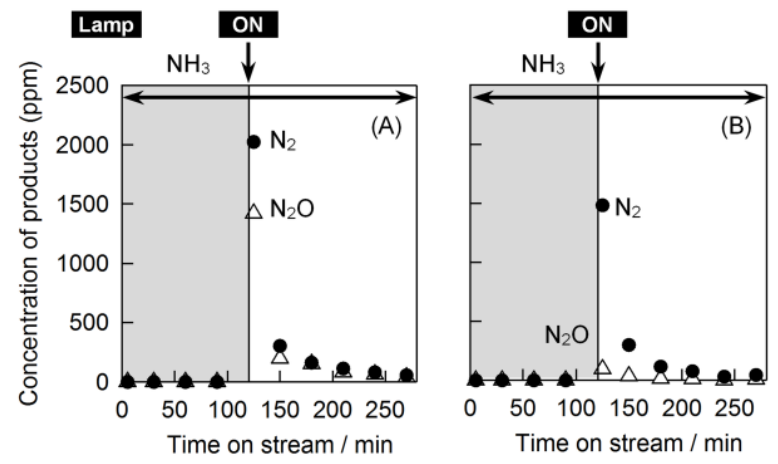

Figure 7. Time course of concentration of $\mathrm{N}_{2}$ and $\mathrm{N}_{2} \mathrm{O}$ in the outlet gas over (A) $\mathrm{NaNO}_{3}$-imprignated $\mathrm{N} 3-\mathrm{TiO}_{2}$ and (B) $\mathrm{NaNO}_{2}$-imprignated $\mathrm{N} 3-\mathrm{TiO}_{2}$. Loading of $\mathrm{NaNO}_{3}$ or $\mathrm{NaNO}_{2}: 1000 \mu \mathrm{mol} \mathrm{g}{ }^{-1}$. Loading of N3-dye: $37.5 \mu \mathrm{mol} \mathrm{g}{ }^{-1}$, Reaction gas: $1000 \mathrm{ppm} \mathrm{NH} / \mathrm{He}$. GHSV: $8000 \mathrm{~h}^{-1}$, light source: $300 \mathrm{~W} \mathrm{Xe}$ lump equipped with a L42 cut-off filter.

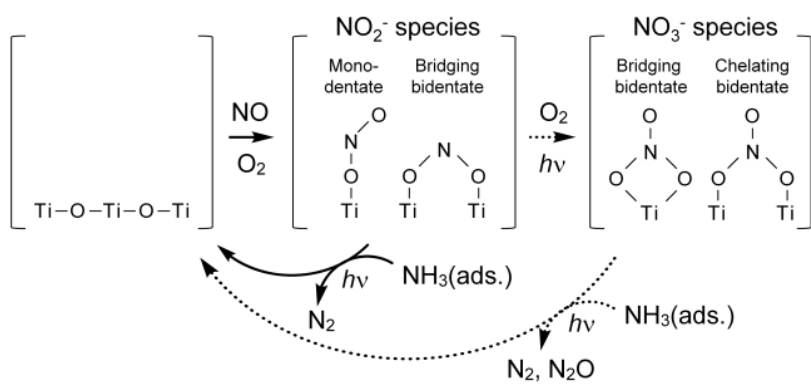

Scheme 1. Surface $\mathrm{NO}_{x}$ species on $\mathrm{N} 3-\mathrm{TiO}_{2}$ catalyst and its reactivity with $\mathrm{NH}_{3}$ under visible light irradiation.

Role of dyes. As shown in Table 1, the activity of $\mathrm{N} 3-\mathrm{SiO}_{2}$ catalyst was very low (conversion of NO: $1.6 \%$, entry 7 ), which indicated that the N3-dye did not function independently of the support (i.e., $\mathrm{TiO}_{2}$ ). Thus, the reaction over $\mathrm{N} 3-\mathrm{TiO}_{2}$ proceeds via a dye-sensitization mechanism: visible-light irradiation induces the electron injection from photo-excited dyes to the conduction band of $\mathrm{TiO}_{2}$. A similar result was obtained in porphyrin-modified $\mathrm{TiO}_{2}$ photocatalysts. ${ }^{[8]}$ After the electron injection, the oxidation product of N3-dye and an electron in the conduction band of $\mathrm{TiO}_{2}$ should be generated as shown in eq. 2:

$\mathrm{N} 3-\mathrm{dye}+\mathrm{hv} \rightarrow \mathrm{N} 3-\mathrm{dye}^{+}+\mathrm{e}_{\mathrm{cb}}^{-}$

Based on eq. 2, we investigated the reactivity of the oxidation product of N3-dye with $\mathrm{NH}_{3}$. In a previous report, ${ }^{[21]}$ the oneelectron oxidation product of $\mathrm{Ru}^{2+}(\mathrm{bpy})_{3}$ (i.e., $\mathrm{Ru}^{3+}(\mathrm{bpy})_{3}$ ) in zeolite was prepared using $\mathrm{Cl}_{2}$ as an oxidant, and we attempted the corresponding oxidation of N3-dye. However, N3-dye ${ }^{+}$could not be prepared because of its instability, although an oxidized N3-dye species, which underwent further transformations from N3-dye ${ }^{+}$, reacted with $\mathrm{NH}_{3}$ and returned to the initial state (for details, see ESI). Therefore, we used the $\mathrm{TiO}_{2}$ photocatalyst modified with $\mathrm{Ru}^{2+}(\mathrm{bpy})_{3} \mathrm{Cl}_{2}$ (4 in Fig. 1) in the UV-Vis spectroscopic study and investigated the reactivity of $\mathrm{Ru}^{3+}(\mathrm{bpy})_{3}$ with $\mathrm{NH}_{3}$ (Fig. 8). After the evacuation of $\mathrm{Ru}(\mathrm{bpy})_{3} \mathrm{Cl}_{2} / \mathrm{TiO}_{2}$, an adsorption band at $455 \mathrm{~nm}$ was observed (spectrum (a) in Fig. 8) and attributed to an MLCT band of $\mathrm{Ru}^{2+}(\mathrm{bpy})_{3}$. After the addition of $\mathrm{Cl}_{2}$, the catalyst color changed from light orange to slightly greyish orange and the adsorption at 600-800 nm increased (spectra (b)), which was assigned to an LMCT band of $\mathrm{Ru}^{3+}(\mathrm{bpy})_{3}{ }^{[21]}$ As previously mentioned, $\mathrm{Ru}^{3+}(\mathrm{bpy})_{3}$ was successfully prepared on the $\mathrm{TiO}_{2}$ surface by using $\mathrm{Cl}_{2}$ as an oxidant. Subsequent introduction of $\mathrm{NH}_{3}$ to the cell resulted in a decrease in the adsorption at 600-800 nm (spectra (c)), which clearly showed the reaction of $\mathrm{Ru}^{3+}(\mathrm{bpy})_{3}$ with $\mathrm{NH}_{3}$ and reduction to the initial $\mathrm{Ru}^{2+}(\mathrm{bpy})_{3}$ species. The UV-Vis spectroscopic result shows that $\mathrm{Ru}^{3+}(\mathrm{bpy})_{3}$ has the potential to oxidize $\mathrm{NH}_{3}$. We concluded that $\mathrm{Ru}^{3+}(\mathrm{bpy})_{3}$, generated after the electron injection, activates $\mathrm{NH}_{3}$ to an $\mathrm{NH}_{2}$ radical (eq. 3), ${ }^{[16]}$ which reacts with $\mathrm{NO}_{2}^{-}$to form $\mathrm{N}_{2}$ selectively. ${ }^{[4 \mathrm{~b}, 16]}$

$\mathrm{Ru}^{3+}(\text { bpy })_{3}+\mathrm{NH}_{3} \rightarrow \mathrm{Ru}^{2+}(\text { bpy })_{3}+\mathrm{NH}_{2}$ radical $+\mathrm{H}^{+}$

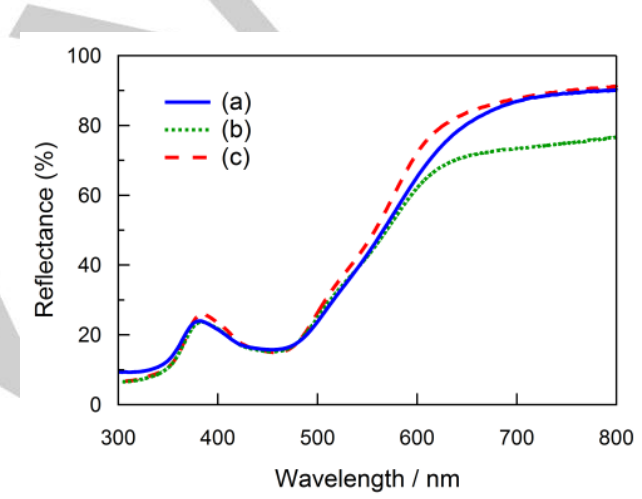

Figure 8. UV-Vis DR spectra of the $\mathrm{TiO}_{2}$ photocatalyst modified with $\mathrm{Ru}(\mathrm{bpy})_{3} \mathrm{Cl}_{2}$ after evacuation (a), after addition of $\mathrm{Cl}_{2}$, and after addition of $\mathrm{NH}_{3}$. Dye loading: $37.5 \mu \mathrm{mol} \mathrm{g}^{-1}$

Proposed reaction mechanism and effects of dyes on the activity. Based on the results obtained thus far, we proposed the reaction mechanism of photo-SCR over Ru-dye-modified $\mathrm{TiO}_{2}$ photocatalysts under visible-light irradiation (Scheme 2). The mechanism is composed of five steps: (1) adsorption of NO and $\mathrm{NH}_{3}$ on the catalyst surface, (2) electron injection from photo-excited $\mathrm{Ru}$ dyes into the conduction band of $\mathrm{TiO}_{2}$, (3) activation of $\mathrm{NH}_{3}$ by oxidized $\mathrm{Ru}$ dyes, (4) surface reaction between an $\mathrm{NH}_{2}$ radical and $\mathrm{NO}_{2}^{-}$, and (5) re-oxidation of $\mathrm{Ti}^{3+}$ sites by $\mathrm{O}_{2}$.

In DSSCs, Ru complexes have shown the best photovoltaic properties among a huge number of dyes, ${ }^{[9 b]}$ and N3-dye was known to be an effective Ru dye for DSSCs due to 1) the wide adsorption range to $800 \mathrm{~nm}, 2$ ) strong adsorption on the semiconductor surface due to binding with up to four carboxyl groups, and 3) sufficiently long excited state life-time $(\sim 20 \mathrm{~ns})^{[9 \mathrm{~b}]}$. In our research, N3-dye showed the highest activity in photoSCR under visible-light irradiation among the 15 dyes studied. The adsorption of N3-dye was not larger than other dyes as shown in Fig. 9 (UV-Vis adsorption spectra of other dyes studied are shown in Fig. S2). This result indicated that the highest activity was not due to the adsorption amount in the 
visible region, although this should be a significant factor. In the case of DSSCs, carboxylic groups were necessary in terms of the strong adsorption of dyes on the semiconductor surface, and the strong adsorption led to strong photovoltaic properties. In this research, $\mathrm{Ru}(\mathrm{bpy})_{3} \mathrm{Cl}_{2}$ dye, which does not possess a carboxylic group, also showed high activity (conversion of $\mathrm{NO}=$ $70.5 \%$ ). A similar result for photo-SCR was obtained in our previous reports using the porphyrin-modified $\mathrm{TiO}_{2}$ photocatalysts with different functional groups. ${ }^{[8]}$ Therefore, carboxylic groups were not important to improve the activity, unlike the DSSCs system. Thus, the life-time of the photoexcited state and the reactivity of the oxidized product of dyes with $\mathrm{NH}_{3}$, which should affect reaction steps 2 and 3 in Scheme 2 , would have a significant effect on the photo-SCR activity.

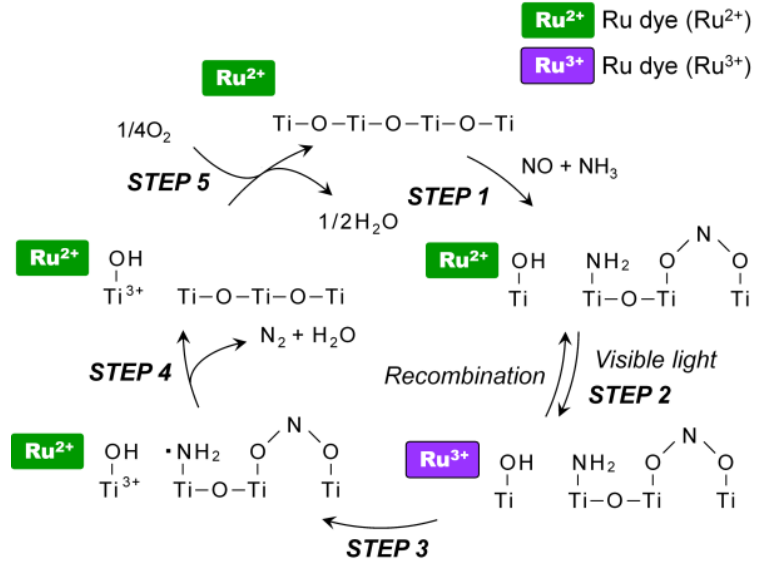

Scheme 2. Proposed reaction mechanism of photo-SCR under visible-light irradiation over $\mathrm{Ru}$ complexes modified $\mathrm{TiO}_{2}$ photocatalyst.

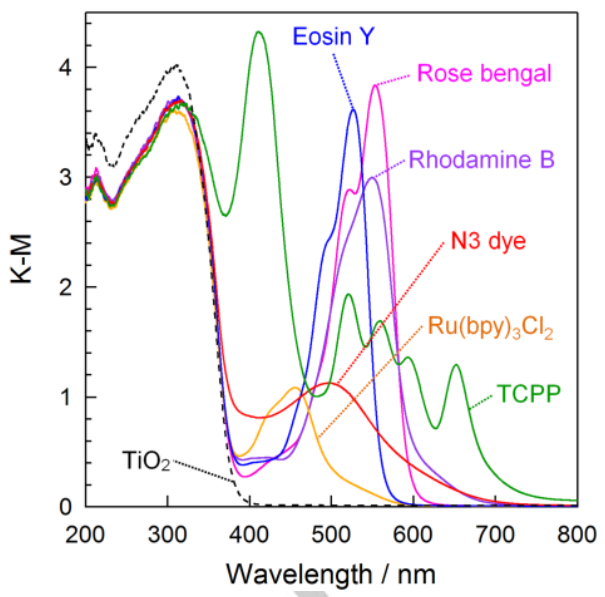

Figure 9. UV-Vis DR spectra of the dye-modified $\mathrm{TiO}_{2}$ photocatalysts. Dye loading: $12.5 \mu \mathrm{mol} \mathrm{g}^{-1}$.

\section{Conclusions}

We demonstrated high-performance photocatalysts for $\mathrm{NH}_{3}$-SCR under visible-light irradiation by combining popular dyes with
$\mathrm{TiO}_{2}$ photocatalysts. The screening of 15 dyes displayed that N3-dye was most effective for the modification of $\mathrm{TiO}_{2}$. Complete conversion of $\mathrm{NO}$ and selectivity to $\mathrm{N}_{2}$ were achieved over N3$\mathrm{TiO}_{2}$ at a high GHSV of $100000 \mathrm{~h}^{-1}$ after 30 min of visible-light irradiation. We proposed a reasonable reaction mechanism of the photo-SCR over dye-modified $\mathrm{TiO}_{2}$ photocatalysts under visible light irradiation by using in situ DRIFT and UV-Vis DR spectroscopies. The reaction proceeds via electron injection from dyes excited by visible-light irradiation into the conduction band of $\mathrm{TiO}_{2}$ (dye-sensitization). The dye oxidation product, generated after the electron injection, oxidatively activates $\mathrm{NH}_{3}$, which then reacts with surface $\mathrm{NO}_{2}^{-}$through the LangmuirHinshelwood mechanism, to provide selective formation of $\mathrm{N}_{2}$.

\section{Experimental Section}

Catalyst preparation. All dyes were used without further purification, and their structures are shown in Fig. 1. The dyes were impregnated on a $\mathrm{TiO}_{2}$ powder (ST-01, anatase, $273 \mathrm{~m}^{2} \mathrm{~g}^{-1}$ ), purchased from Ishihara Sangyo Kaisha, Ltd., using appropriate solvents (see ESI). Sodium nitrite $\left(\mathrm{NaNO}_{2}\right)$ and sodium nitrate $\left(\mathrm{NaNO}_{3}\right)$ were impregnated on the N3-dyemodified photocatalyst using water as the solvent (loading of $\mathrm{NaNO}_{2}$ or $\mathrm{NaNO}_{3}: 1000 \mu \mathrm{mol} \mathrm{g}{ }^{-1}$ ).

Photocatalytic reaction. Photo-SCR was carried out in a conventional fixed-bed flow system at atmospheric pressure, the details of which we have previously reported. ${ }^{[4 b, 8]}$ In brief, two types of a quartz reactor were used in this research: reactor $1(12 \mathrm{~mm} \times 10 \mathrm{~mm} \times 1.0 \mathrm{~mm}$, catalyst amount: $110 \mathrm{mg}$ ) for a GHSV of 100000 and $250000 \mathrm{~h}^{-1}$, and reactor 2 $(50 \mathrm{~mm} \times 15 \mathrm{~mm} \times 1.0 \mathrm{~mm}$, catalyst amount: $420 \mathrm{mg})$ for a GHSV of $8000 \mathrm{~h}^{-1}$. The reaction gas (NO $1000 \mathrm{ppm}, \mathrm{NH}_{3} 1000 \mathrm{ppm}, \mathrm{O}_{2} \%, \mathrm{He}$ balance) was introduced to the reactors at a flow rate of $100-500 \mathrm{~mL}$ $\mathrm{min}^{-1}$. A $300 \mathrm{~W}$ Xe lamp (PERKIN-ELMER PE300BF) equipped with an L42 cut-off filter was used as a light source $(\lambda>400 \mathrm{~nm}) . \mathrm{N}_{2}$ and nitrous oxide $\left(\mathrm{N}_{2} \mathrm{O}\right)$ were analyzed using two SHIMADZU GC-8A TCD gas chromatographs.

Characterization. In situ DRIFT measurements were performed with a JASCO ISDR-600 FTIR spectrometer equipped with a mercurycadmium-tellurium (MCT) detector cooled by liquid $\mathrm{N}_{2}$ at a resolution of 4 $\mathrm{cm}^{-1}$ and with $16 \mathrm{co}$-added scans. The sample powder $(50 \mathrm{mg})$ was placed in a DR cell, which was fitted with a $\mathrm{KBr}$ window at the top. The catalyst was pretreated at $353 \mathrm{~K}$ under a He gas flow $\left(100 \mathrm{~mL} \mathrm{~min}{ }^{-1}\right)$ for $1 \mathrm{~h}$, and was then cooled to room temperature. Concentrations of gases were the same as in the reaction. The background spectrum was measured after the pretreatment in a He gas flow at room temperature. A $200 \mathrm{~W} \mathrm{Hg}-\mathrm{Xe}$ lamp equipped with a collective lens (San-Ei Electric Co. Ltd., UVF-204S type C) was used as a light source, and light was irradiated through an L42 cut-off filter. UV-Vis DR spectra were measured using a UV-Vis spectrometer (JASCO V-650) with an integrating sphere. $\mathrm{A} \mathrm{BaSO}_{4}$ plate was used as a reference. A sample powder was added to a quartz cell with flat facets and evacuated at 373 $\mathrm{K}$ for $1 \mathrm{~h}$ before the measurement. $\mathrm{Cl}_{2}$ and $\mathrm{NH}_{3}$ gas were added to the cell using a vacuum line.

\section{Acknowledgements}

This study was partially supported by the Program for Element Strategy Initiative for Catalysts \& Batteries (ESICB), 
commissioned by the Ministry of Education, Culture, Sports, Science and Technology (MEXT) of Japan, and the Precursory Research for Embryonic Science and Technology (PRESTO), supported by the Japan Science and Technology Agency (JST). Akira Yamamoto thanks the JSPS Research Fellowships for Young Scientists.

Keywords: Photocatalysis - Nitrogen oxides - Dyes • Environmental chemistry $\cdot \mathrm{NH}_{3}-\mathrm{SCR}$

[1] a) H. Bosch, F. Janssen, Catal. Today 1988, 2, 369-379; b) G. Busca, L. Lietti, G. Ramis, F. Berti, Appl. Catal. B 1998, 18, 1-36; c) P. Forzatti, L. Lietti, Heterog. Chem. Rev. 1996, 3, 33-51.

[2] a) J. A. Sullivan, J. Cunningham, M. A. Morris, K. Keneavey, Appl. Catal. B 1995, 7, 137-151; b) R. Q. Long, R. T. Yang, J. Am. Chem. Soc. 1999, 121, 5595-5596; c) A.-Z. Ma, W. Grunert, Chem. Commun. 1999, 71-72; d) R. Q. Long, R. T. Yang, J. Catal. 2002, 207, 224-231.

[3] L. Dana, K. Fanta, 2012.

[4] a) T. Tanaka, K. Teramura, K. Arakaki, T. Funabiki, Chem. Commun. 2002, 2742-2743; b) K. Teramura, T. Tanaka, S. Yamazoe, K. Arakaki, T. Funabiki, Appl. Catal. B 2004, 53, 29-36; c) S. Yamazoe, T. Okumura, K. Teramura, T. Tanaka, Catal. Today 2006, 111, 266-270; d) A. Yamamoto, Y. Mizuno, K. Teramura, T. Shishido, T. Tanaka, Catal. Sci. Technol. 2013, 3, 1771-1775.

[5] a) K. Teramura, T. Tanaka, T. Funabiki, Langmuir 2003, 19, 1209 1214; b) K. Teramura, T. Tanaka, T. Funabiki, Chem. Lett. 2003, 32 , 1184-1185.

[6] a) Y.-C. Chou, Y. Ku, Chem. Eng. J. 2010, 162, 696-701; b) Y. Chou, Y. Ku, Front. Environ. Sci. Eng. 2012, 6, 149-155.

[7] Y. Ji, Y. Luo, J. Phys. Chem. C 2014, 118, 6359-6364.

[8] A. Yamamoto, Y. Mizuno, K. Teramura, S. Hosokawa, T. Shishido, T. Tanaka, Catal. Sci. Technol. 2015, 5, 556-561.

[9] a) A. Kay, M. Graetzel, J. Phys. Chem. 1993, 97, 6272-6277; b) A. Hagfeldt, G. Boschloo, L. Sun, L. Kloo, H. Pettersson, Chem. Rev. 2010, 110, 6595-6663; c) N. Robertson, Angew. Chem. Int. Ed. 2006, 45, 2338-2345

[10] a) R. Abe, K. Shinmei, N. Koumura, K. Hara, B. Ohtani, J. Am. Chem. Soc. 2013, 135, 16872-16884; b) R. Abe, K. Shinmei, K. Hara, B. Ohtani, Chem. Commun. 2009, 3577-3579; c) R. Abe, K. Sayama, H. Arakawa, J. Photochem. Photobiol. A 2004, 166, 115-122; d) K. Takanabe, K. Kamata, X. Wang, M. Antonietti, J. Kubota, K. Domen, PCCP 2010, 12, 13020-13025.

[11] a) T. Hannappel, B. Burfeindt, W. Storck, F. Willig, J. Phys. Chem. B 1997, 101, 6799-6802; b) M. R. Waterland, D. F. Kelley, J. Phys. Chem. A 2001, 105, 4019-4028; c) R. Katoh, A. Furube, T. Yoshihara, K. Hara, G. Fujihashi, S. Takano, S. Murata, H. Arakawa, M. Tachiya, J. Phys. Chem. B 2004, 108, 4818-4822.

[12] a) B. O'Regan, M. Gratzel, Nature 1991, 353, 737-740; b) Y. Lu, D.-j. Choi, J. Nelson, O. B. Yang, B. A. Parkinson, J. Electrochem. Soc. 2006, 153, E131; c) H. Rensmo, S. Lunell, H. Siegbahn, J. Photochem. Photobiol. A 1998, 114, 117-124; d) M. K. Nazeeruddin, A. Kay, I. Rodicio, R. Humphry-Baker, E. Mueller, P. Liska, N. Vlachopoulos, M. Graetzel, J. Am. Chem. Soc. 1993, 115, 6382-6390.

[13] a) W. M. Campbell, A. K. Burrell, D. L. Officer, K. W. Jolley, Coord. Chem. Rev. 2004, 248, 1363-1379; b) H. Imahori, T. Umeyama, S. Ito, Acc. Chem. Res. 2009, 42, 1809-1818; c) T. Ma, K. Inoue, H. Noma, K. Yao, E. Abe, J. Photochem. Photobiol. A 2002, 152, 207-212; d) F. Odobel, E. Blart, M. Lagree, M. Villieras, H. Boujtita, N. El Murr, S. Caramori, C. Alberto Bignozzi, J. Mater. Chem. 2003, 13, 502-510; e) A Yella, H.-W. Lee, H. N. Tsao, C. Yi, A. K. Chandiran, M. K. Nazeeruddin, E. W.-G. Diau, C.-Y. Yeh, S. M. Zakeeruddin, M. Grätzel, Science 2011, 334, 629-634; f) H. Hagiwara, N. Ono, T. Inoue, H. Matsumoto, T. Ishihara, Angew. Chem. Int. Ed. 2006, 45, 1420-1422; g)
H. Hagiwara, T. Inoue, S. Ida, T. Ishihara, PCCP 2011, 13, 1803118037.

[14] a) M. K. Nazeeruddin, R. Humphry-Baker, M. Gratzel, M. K. Nazeeruddin, R. Humphry-Baker, M. Gratzel, B. A. Murrer, Chem. Commun. 1998, 719-720; b) S. Eu, T. Katoh, T. Umeyama, Y. Matano, H. Imahori, Dalton Trans. 2008, 5476-5483; c) V. Aranyos, J. Hjelm, A Hagfeldt, H. Grennberg, J. Porphyrins Phthalocyanines 2001, 05, 609616; d) A. Morandeira, I. López-Duarte, M. V. Martínez-Díaz, B. O'Regan, C. Shuttle, N. A. Haji-Zainulabidin, T. Torres, E. Palomares, J. R. Durrant, J. Am. Chem. Soc. 2007, 129, 9250-9251.

[15] a) K. Hara, Z.-S. Wang, T. Sato, A. Furube, R. Katoh, H. Sugihara, Y. Dan-oh, C. Kasada, A. Shinpo, S. Suga, J. Phys. Chem. B 2005, 109 , 15476-15482; b) T. Horiuchi, H. Miura, S. Uchida, Chem. Commun. 2003, 3036-3037.

[16] S. Yamazoe, K. Teramura, Y. Hitomi, T. Shishido, T. Tanaka, J. Phys Chem. C 2007, 111, 14189-14197.

[17] Y. J. Kim, H. J. Kwon, I. Heo, I.-S. Nam, B. K. Cho, J. W. Choung, M.-S. Cha, G. K. Yeo, Appl. Catal. B 2012, 126, 9-21.

[18] Y. Ooyama, Y. Harima, Eur. J. Org. Chem. 2009, 2009, 2903-2934.

[19] a) D. V. Pozdnyakov, V. N. Filimonov, Kinet. Katal. 1973, 14, 760; b) K. I. Hadjiivanov, Cat. Rev. - Sci. Eng. 2000, 42, 71-144.

[20] a) H. Knözinger, P. Ratnasamy, Catal. Rev. 1978, 17, 31-70; b) G. Munuera, V. Rives-Arnau, A. Saucedo, J. Chem. Soc., Faraday Trans. 11979, 75, 736-747.

[21] W. H. Quayle, J. H. Lunsford, Inorg. Chem. 1982, 21, 97-103. 


\section{Entry for the Table of Contents}

Layout 1:

\section{FULL PAPER}

Dye-sensitized $\mathrm{TiO}_{2}$ photocatalysts showed high photocatalytic activity for selective catalytic reduction of $\mathrm{NO}$ with $\mathrm{NH}_{3}\left(\mathrm{NH}_{3}\right.$-SCR) under visiblelight irradiation. DRIFT and reactions under various conditions revealed that surface $\mathrm{NO}_{2}^{-}$species is an intermediate in the reaction and reacts with adsorbed $\mathrm{NH}_{3}$ under visible-light irradiation to selectively form $\mathrm{N}_{2}$.
Author(s), Corresponding Author(s)*

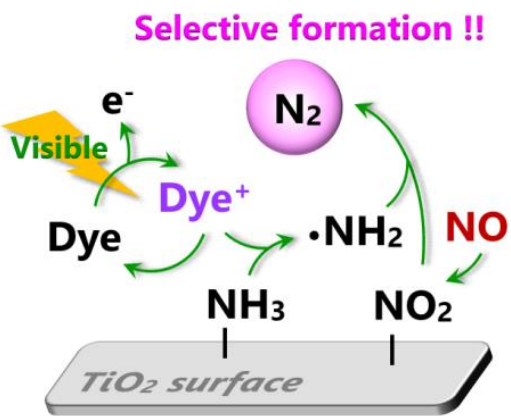

Page No. - Page No.

Title 


\section{Supporting Information}

\section{Preparation of catalyst}

The dye-modified $\mathrm{TiO}_{2}$ photocatalysts were prepared by a simple impregnation method using organic solvent as shown Table S1.

Table S1. Solvent used for the impregnation

\begin{tabular}{lll}
\hline Entry & Dye & Solvent used for the impregnation \\
\hline 1 & N3 dye ${ }^{[\mathrm{a}]}$ & Methanol \\
2 & Rose bengal & Methanol \\
3 & Eosin Y & Methanol \\
4 & Ru(bpy) ${ }_{3} \mathrm{Cl}_{2}$ & Methanol \\
5 & Rhodamine B & Methanol \\
6 & Coumarin 343 & Methanol \\
7 & TCPP ${ }^{[b]}$ & Methanol \\
8 & Methylene blue & Methanol \\
9 & Zn phthalocyanine & Trifluoroacetic acid \\
10 & Congo red & Water \\
11 & Phthalocyanine & Trifluoroacetic acid \\
12 & RhCl ${ }_{3}$ & Water \\
13 & Indigo carmine & Water \\
14 & Cu phthalocyanine & Trifluoroacetic acid \\
\hline 15 & Carmine & maOH aq. \\
\hline
\end{tabular}

${ }^{[a]} \mathrm{Ru}(4,4 \text { '-dicarboxy-2,2'-bipyridine })_{2}(\mathrm{NCS})_{2}$

[b] Tetrakis(4-carboxyphenyl)porphyrin 


\section{Reactivity of oxidation product of $\mathbf{N} 3$ dye}

As shown in the main text, we tried to prepare the one electron oxidation product of N3dye using $\mathrm{Cl}_{2}$ as an oxidant. Figure $\mathrm{S} 1$ shows the UV-Vis DR spectra of N3-dye and the photographs of the catalysts. After evacuation, the catalyst color was the dark purple (a), and an absorption band at $515 \mathrm{~nm}$ was observed. The band is assigned to a MLCT band of the grand state $\mathrm{N} 3$-dye $\left(\mathrm{Ru}^{2+}\right)$. After addition of $\mathrm{Cl}_{2}$, the catalyst color changed from dark purple into ocher (b), and the absorption peak was shifted to $420 \mathrm{~nm}$. The band at $420 \mathrm{~nm}$ is not attributed to the one electron oxidation products $\left(\mathrm{Ru}^{3+}\right)$ of $\mathrm{N} 3$-dye because the one electron oxidation product have an adsorption band around $740 \mathrm{~nm}$, which was observed in several transient adsorption experimen. ${ }^{[1,2]}$

S. Das and P. V. Kamat ${ }^{[2]}$ investigated the oxidized form of N3-dye by using transient absorption spectroscopy using azide (N3•) radical generated by $\gamma$-Radiolysis as an oxidant. Their results provided the spectral evidence for the formation of two different species that follow the oxidation of N3 dye. One oxidized product (species 1, abs. max: $740 \mathrm{~nm}$ ) was attributed to the one-electron oxidation product of N3-dye, and is undergone further transformations to the other oxidized form (species 2, abs. max: 440 $\mathrm{nm})$ at room temperature. The identification of species 2 was not made in their report. The ocher products (abs. max: $420 \mathrm{~nm}$ ) observed in our UV-Vis DR experiments can be assigned to the species 2 judging from the position of adsorption maximum.

To examine the reactivity of species $2, \mathrm{NH}_{3}$ was introduced to the cell. After addition of $\mathrm{NH}_{3}$, the catalyst color changed into the initial dark purple as shown in Figure S1(c). This result clearly indicates that species 2 can react with $\mathrm{NH}_{3}$ and returned to the initial ground state of $\mathrm{N} 3$ dye (eq. 3 in the main text). Although the identification is not made, and which oxidation products (species 1 or 2) activate $\mathrm{NH}_{3}$ in the in situ reaction condition is unclear, the UV-Vis DR spectroscopy revealed that oxidized products (at least, species 2) of N3-dye have a potential to activate $\mathrm{NH}_{3}$.

[1] S. Das, P.V. Kamat, J. Phys. Chem. B 102 (1998) 8954-8957.

[2] R. Katoh, A. Furube, T. Yoshihara, K. Hara, G. Fujihashi, S. Takano, S. Murata, H. Arakawa, M. Tachiya, J. Phys. Chem. B 108 (2004) 4818-4822. 


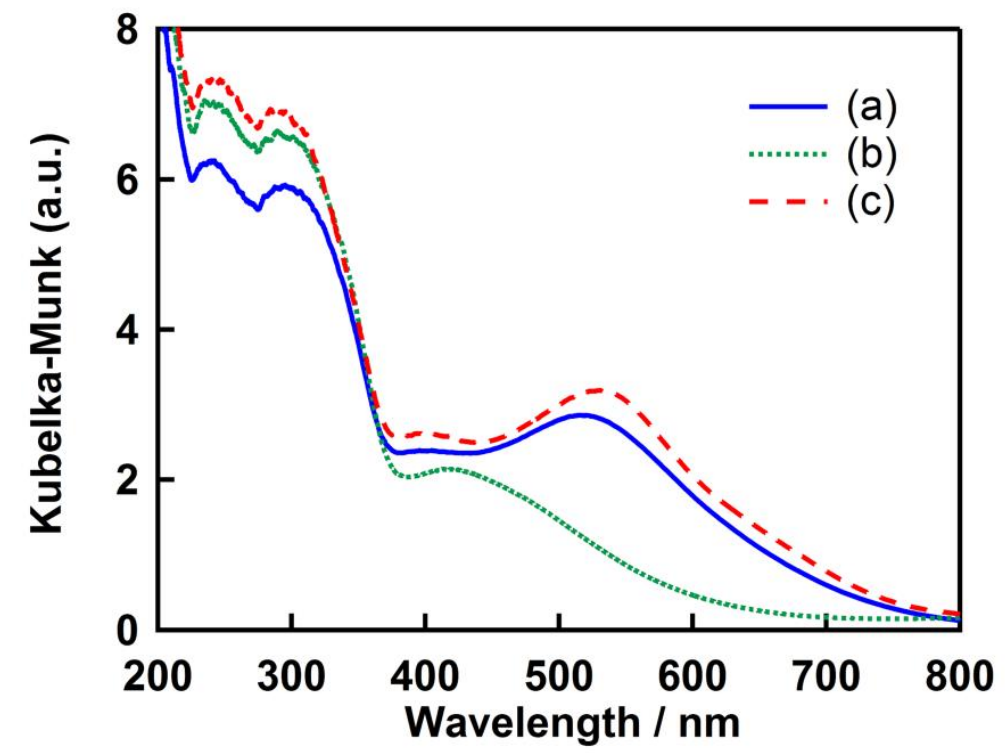

(a)
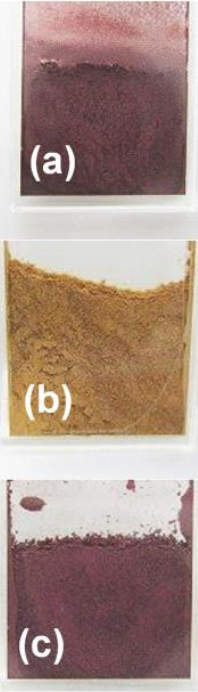

Figure S1. UV-Vis DR spectra and photographs of $37.5 \mu \mathrm{mol} \mathrm{g}^{-1} \quad \mathrm{~N} 3-\mathrm{TiO}_{2}$ photocatalyst after evacuation (a), after addition of $\mathrm{Cl}_{2}$ (b), and after addition of $\mathrm{NH}_{3}$ (c).

\section{UV-Vis DR spectra of dye-modified $\mathrm{TiO}_{2}$ photocatalysts}

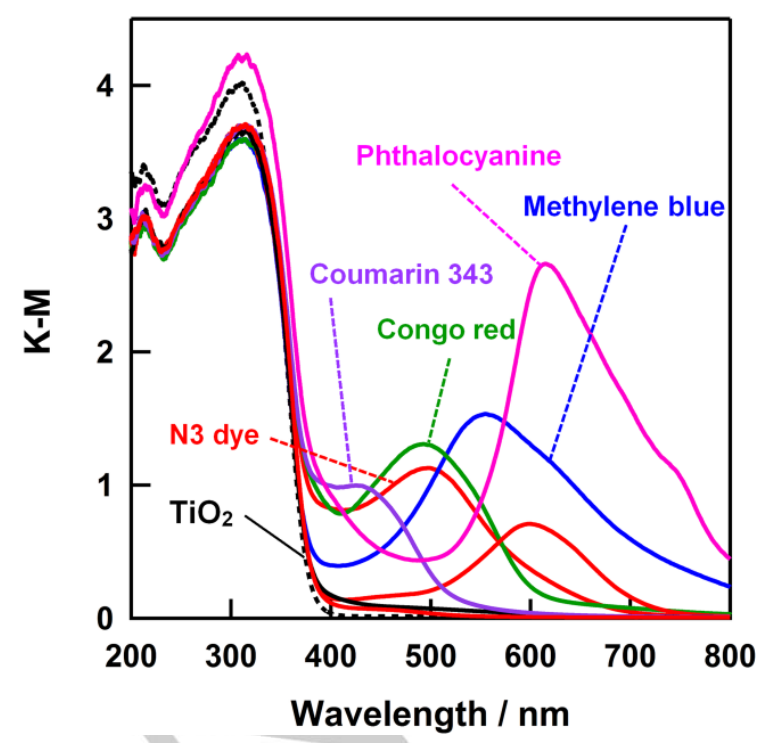

Figure S2. UV-Vis DR spectra of the dye-modified $\mathrm{TiO}_{2}$ photocatalysts. Dye loading: $12.5 \mu \mathrm{mol} \mathrm{g}^{-1}$. 